\title{
Creative Writing Assignments in a Second Language Course: A Way to Engage Less Motivated Students
}

\author{
Ekaterina Arshavskaya, PhD \\ Assistant Professor of English as a Second Language \\ Utah State University
}

\begin{abstract}
This article makes a case for using creative writing in a second language course. Creative writing increases students' enthusiasm for writing skills development and supports students' creativity, which is a fundamental aspect of education. In order to engage less motivated students, a series of creative writing assignments was implemented in a second language writing course. This study presents the rationale for the use of creative writing grounded in critical pedagogy and the context of instruction. Data collection focused on the content of students' writing and their attitudes towards creative writing and critical pedagogy. The results show that all the participating students found the assignment both enjoyable and beneficial for the development of their writing ability. However, the students' perceptions of critical pedagogy varied. The author argues for greater employment of creative writing in second language courses in the future.
\end{abstract}

Second language (L2) composition instructors have long been interested in providing additional language practice opportunities to L2 writers. Plenty of research studies have reported the benefits $L 2$ students gain by engaging in the additional writing practice. For instance, the use of dialogic journals expands the contexts of writing for English as a Second Language (ESL) students and serves as a useful learning strategy (Holmes \& Moulton, 1997). The use of journals leads to increased fluency in writing and greater motivation to write. In addition, students

In order to address the issue of engagement, boost student confidence as L2 writers, and increase writing fluency, a series of creative writing exercises was introduced in the ESL advanced-level writing course during the fall semester of 2014 . are able to learn through models provided by the instructor in his/her responses to journal entries. In this way, students can improve their writing noticeably (McDonald, Rosselli, \& Clifford, 1997). Other researchers point out that in ESL classes there are students who are culturally quieter or students who are uneasy speaking out in English. These students who are reticent to speak in class can use journals to express and share their ideas in writing in a nonthreatening format with instructors and/or peers (Spack \& Sadow, 1983). Finally, response writing can motivate low-achieving students (Lee, 2012) and help promote students' more sophisticated thinking (Bilton \& Sivasubramaniam, 2009).

The idea for this study dates back to 2013, when the author of this article (also, the researcher) started teaching an ESL advanced-level writing course offered to international undergraduate students at an intensive English program in a southwestern American university. Based on the author's own observations, the majority of students struggle with the course content, demonstrating difficulties in a number of areas. The causes of students' struggles can be attributed to: (a) limited English training in high schools and (b) they are not English majors. In addition, students show low levels of engagement with class activities and assignments during class meetings. Also, end-of-semester evaluations show that students are not interested in taking the course from the start. Specifically, the average scores to the item "I really wanted to take this course" were 3.0 and 2.8 (out of 5) for the spring and fall of 2014 semesters respectively.

In order to address the issue of engagement, boost student confidence as L2 writers, and increase writing fluency, a series of creative writing exercises was introduced in the ESL advanced-level writing course during the fall semester of 2014. The creative writing assignments are grounded in critical pedagogy (Freire, 
1970), dealing with the issues related to marginalized groups of people around the world and various kinds of discrimination based on gender, sexual orientation, and/or ideological beliefs. Because of the students' international backgrounds, the topics related to people's lives around the world were selected aiming to attract their potential interest in these issues.

The current study presents the results of implementing a series of creative writing exercises in an advanced-level ESL course. Data collection focused on the content of students' writing and attitudes towards creative writing and critical pedagogy. The study ends with pedagogical implications of the study and suggestions for further research.

\section{Using Expressive and Creative Forms of Writing with L2 Learners}

Recent years witness a growing popularity of using expressive and creative forms of writing with L2 learners. For instance, McDonald et al. (1997) found that the use of expressive writing (dialogic diaries) with ESL students led to qualitative improvements in student writing towards the end of the semester. Additionally, the researchers determined the number of sentences and words in each student's writing at the beginning and the end of the course. They report that that there was little mean change from pre- to post- on any of these ratings; i.e., even though the numbers did go up, but only marginally. In a more recent study, Lee (2012) employed the use of an electronic reading response journal, in which the students expressed their reactions to several literary texts. Lee (2012) reports that the use of expressive writing led to students' overall improvement in writing and that some of the students exhibited great levels of engagement with the assignment by posting poems and other forms of creative writing in addition to their reactions to the texts.

Highlighting the role of expressive writing for L2 writers, Bilton and Sivasubramaniam (2009) argue that today's L2 educators primarily focus on the students' "vocational needs" (p. 303) without paying attention to students' emotional or maturational needs. These researchers explain that the proponents of expressive writing viewed writing as an act of creative expression and a process of discovering meaning (Zamel, 1982). Additionally, by responding to the content of student writing rather than focusing on the grammatical or structural deficiencies, L2 teachers can help "minimize fear, nervousness, and self-consciousness" (Leki, 1992, p. 17) experienced by novice writers. Expressive writing can lead students toward better academic writing (Spack \& Sadow, 1983), because by engaging in expressive writing students learn to focus on ideas and, as a result, their written products improve as well (Zamel, 1982).

In addition, infusing L2 writing curriculum with creative writing exercises can help support students' creativity, one of the fundamental aspects of education. In addition, engagement in creative writing activities helps students experience higher levels of enthusiasm and motivation to improve their writing abilities because they can express themselves freely and employ their imagination (Stillar, 2013).

\section{Applying Critical Pedagogy to L2 Classrooms}

The person who stood at the roots of critical pedagogy is the Brazilian educator, scholar, and human rights activist Paulo Freire. Freire (1970) observed that generally teachers transfer accepted information to their students without connecting it to the realities of students' lives and then require to reproduce it on tests. As the educator of the oppressed, Freire insisted that education is a political act that, if not seen as such, legitimizes and reproduces the politics of the dominant classes, thus maintaining social disparities (Pagliarini Cox \& de Assis-Peterson, 1999). Seeing education as a path to common people's liberation, Freire (1970) proposed that educators engage in a true dialogue with their students, while students problematize reality. In other words, according to Freire, students must learn to identify problems and come to recognize and understand the significance of 
those problems with regard to their own lives and the lives of others. To this end, Freire suggested using activities during which learners name, construct, and critically reflect on the realities of their own lives.

The ideas rooted in critical pedagogy are particularly relevant to the L2 teaching context since language learning involves the issues related to power and domination, while avoiding such conversations "becomes, on the one hand, understandable and, on the other, reprehensible" (Pennycook, 1990, p. 305) affair. By infusing L2 writing curriculum with critical discourse, L2 writing instructors can help students develop critical consciousness and empathy and promote students' exploration of the nature of knowledge and power. Recent research (Stillar, 2013) shows that when adopting new identities (e.g., the identities of marginalized or vilified groups of people in the students' dominant cultures), students attempt to challenge the existing status quo and start to develop critical consciousness in relation to societal inequality. By introducing critical discourse into L2 classrooms, writing instructors call attention to the issues related to social inequality and the role of power in today's society (Stillar, 2013).

Graman (1988) shared a personal account of applying the ideas rooted in critical pedagogy with adult ESL learners. In this account, he explained how he was able to shift away from the mechanical drills in grammar and pronunciation found in ESL textbooks to discussing the issues that were of utmost importance to his farmworking students from several countries in Latin America and Spain, eventually empowering them to name, understand, and problematize the world they found themselves in. Stillar (2013), in his research with Japanese English learners in the English as a Foreign Language (EFL) context, reports on promoting greater critical consciousness on the part of the students by asking them to write personal letters and journal entries from the perspective of the people traditionally marginalized or vilified by the dominant class in their culture.

Overall, this study combines and applies the expressive, creative, and critical pedagogy approaches to writing in an advanced-level ESL writing course. The unique contributions of this research are that it reports the findings that have the potential to help review and renew the existing L2 writing curricula for undergraduate ESL students in the U.S. universities. This study pursued three main research questions: (a) How does the use of creative writing assignments mediate student development of critical consciousness?; (b) What are the students' attitudes towards the use of creative writing activities in an L2 writing course?; and (c) What are the students' perceptions of the use of critical pedagogy in an L2 writing course?

\section{Method}

\section{Participants}

The participants included nine international undergraduate students (four female and five male participants) in their twenties enrolled in an advanced-level academic writing course offered at a southwestern American university during the fall of 2014. The students came from diverse countries such as the Dominican Republic, Slovenia, Iran, South Korea, and Portugal who majored in a number of disciplines such as electrical engineering, landscape architecture, nutrition, and aviation.

The study was conducted with the IRB approval. The creative writing assignments constituted a required part of the advanced-level ESL writing course content. However, this article utilizes the writing excerpts of students who agreed to participate in the research. ${ }^{1}$ In order to protect research participants' privacy, the participants' names are not disclosed.

Upon the end of the academic semester, students completed a survey asking them about their attitudes and perceptions with regards to the creative

${ }^{1}$ Only 7 students allowed me to cite from their essays. 
writing assignments and critical pedagogy. The end-of-semester survey questions are provided in Appendix A.

\section{Instructional Context}

The ESL academic writing course is designed to teach international firstyear undergraduate students common practices associated with academic writing, such as how to summarize an academic text, how to paraphrase and quote from sources, how to choose research topics, conduct library research, organize textual and other kinds of evidence, and use a citation style. In addition, students engage in pre-writing activities and in-class peer reviews, and learn how to revise their academic essays and how to edit their own writing for common grammatical errors.

A set of creative writing assignments was designed by the course instructor (see Appendix B). The assignments required the students to carry out basic library research and consult peers and friends in relation to the topics of the assignments. In this way, the assignments fulfilled one of the course goals. Prior to being assigned with a series of creative assignments, the students were introduced to such concepts as dominant and marginalized groups of people, the notions of critical consciousness, empathy, knowledge, and power in an oral class discussion. Students' writing was graded based on the content (i.e., idea development, persuasive evidence) rather than grammatical, structural or spelling errors.

\section{Mode Inquiry}

Grounded in the qualitative methodology approach (Strauss \& Corbin, 1998), this study focuses on the content of student writing and student responses to the end-of-semester survey questions. In order to arrive at a view of the participants' experiences, the research design employed grounded theory (Glaser \& Strauss, 1967). According to this approach, in order to ascribe a meaning to the experiences of the participants, a researcher must pay attention to the most prominent and recurrent themes in the data.

Data analysis proceeded in two stages. Each time a creative written assignment was submitted by a student, the researcher wrote interpretive memos about the nature of the topics discussed. These memos initially corresponded to the two broad categories identified in literature, which provided the initial guiding framework: critical consciousness and empathy. The second stage of analysis occurred at the end of the course when all assignments and the responses to the end-of-semester survey were collected and a detailed content analysis was carried out. Students' written assignments and responses were read and re-read repeatedly by the researcher. Recurrent concepts and themes were identified through the researcher's multiple rounds of re-reading the data. Each written sample was divided into topics, coded, and sorted into categories, many of which identified from the content analysis and modified the initial categories. For example, a new category "indifference" was created during the analysis and informed the researcher's further investigations and readings.

\section{Results}

\section{Research Question 1}

To answer the first research question of whether the use of creative writing assignments mediate students' critical consciousness development, the researcher analyzed both the students' replies in the end-of-semester survey as well as the content of students' writing during the course. Appendix C summarizes students' replies to several selected questions from the survey. As can be seen, the majority of the participating students reported on experiencing a greater extent of empathy and critical consciousness as a result of their engagement in the creative writing 
activities. At the same time, all but one of the students, were enthusiastic in using the same set of exercises with future students.

In their written assignments, the majority of students also showed a greater extent of critical consciousness towards the end of the semester. For example, while in the first assignment A Day in the Life of a North Korean, only two students shared some critical comments about the existing political regime and its elite, in their third assignment $A$ Letter of a Young Saudi Woman, all but two students resisted their parental disapproval of their intention to study abroad. The following excerpt from a student's third assignment $A$ Letter of a Young Saudi Woman demonstrates the student's ability to exercise her critical thinking skills by recognizing and opposing unstated societal assumptions and values. Here and hereafter, the text in bold indicates the more salient parts of the data, representing more relevance for the article's research questions.

Excerpt 1. I always wanted to study in the United States but now I realize that it is a difficult step for me because of the ideas about women and women's role in this country. The only possibility for me is that I can get in contact with someone of Islam community in the U.S. to become my guardian on the trip. Is there someone you know that I can contact?

Moreover, in the second assignment $A$ Letter to an LGBT Friend, all the students wrote about their intention both to maintain the friendship and to continue interacting with parents with the purpose of eventually persuading them to accept this friendship. The excerpt below from a student's second assignment $A$ Letter to an LGBT Friend shows her ability to evaluate an argument and propose an accurate alternative judgement:

Excerpt 2. My parents consider these people [LGBT] as outsiders, not a part of society and when I told them about you [an LGBT friend] I was embarrassed by their reaction. ... But anyways we had a long talk and cleared things up and now I think we are even closer. In the end, they realized that our friendship is not a bad thing for me or will affect me in some way.

The causes of student $s^{\prime}$ greater extent of critical consciousness can be attributed to: (a) their familiarity with the topics of the assignments and (b) their attitudes towards the marginalized groups of people discussed in the assignments. For instance, with regards to the first assignment, it was perceived by all the students as the most difficult. In their responses to the end-of-semester survey, two of the students wrote that even though they were aware of the situation in North Korea, they had to carry out some research to find out the details, which was time-consuming. In addition, one of the students said that he was not comfortable writing about North Korea since he doubted that it was possible to obtain accurate information about the country. Students' lack of familiarity with the situation in North Korea might have prompted them to describe it in neutral terms rather than to critically evaluate it. Also, students' attitudes towards

In their written assignments, the majority of students also showed a greater extent of critical consciousness towards the end of the semester.

the groups of people discussed in the assignments influenced the nature of their writing. For example, a student from South Korea wrote that in her country it was not customary to talk about the situation in North Korea because people did not care (indifference). As a result, her journal entry was described in a neutral manner. In contrast, in his assignment, another student used the following expressions: "in my oppressed country" and "glorious party (sarcastic)". In his assignment, the same student mentioned that he resisted the regime by smoking self-made cigarettes. In his response to the end-of-semester survey, he said the following: "For the first journal, it was truly appalling to know how people are being treated in that isolated country." Apparently, his initial attitude of empathy rather than indifference prompted him to share some critical comments about the existing 
regime. Another critically-minded student admitted contemplating her escape from the country and describing the elite as "they are the only ones who can afford Western brands and goods, they can pay in euros and dollars."

In their responses to the second assignment dealing with the parents' disapproval of their friendship with a member of the LGBT community, all students showed their determination to resist their parents' decision. Some of the students justified their parents' negative reactions by their religious affiliations (e.g., Mormon, Muslim). Interestingly, one of the students returned to this topic (LGBT) in the last (fourth) assignment, probably finding it particularly relevant. In contrast to the first assignment, students had greater awareness of the issues related to the LGBT community. Also, they might have found it easier to resist their parents' decision rather than the policies of a country's regime.

Similar claims can be made in relation to the third assignment, which required students to write a letter to a U.S. pen friend from the perspective of a young Saudi woman whose intention to study abroad is not supported by her parents. All but two students found a resolution to the problem. The excerpt below illustrates one of such solutions.

Excerpt 3. I have been talking to Aladdin [guardian's name] a lot. He is an encouraging person and really comprehensible, therefore, he would like to help me. We thought that I can go to study abroad, and he can accompany me.

In the excerpt above, the student decides to ask a male guardian from her home country to accompany her on her trip to study abroad, while another student writes about a guardian in the U.S. Some other student requests advice from her pen-friend in the U.S. about how she managed to come to the U.S. despite parental disapproval of her decision, while a different student mentions a supportive husband. Overall, completing this assignment, the majority of the students demonstrated their ability to recognize a societal problem and offer a viable solution. Interestingly, completing this assignment, one of the students also provided a translation of her assignment in Arabic, whereas another student wrote the text in English and the signature in Arabic.

Finally, students' responses to the fourth writing prompt (see Appendix A) also illustrate students' ability to recognize and critically evaluate unstated unfair assumptions and beliefs:

Excerpt 4. People got into a fight with us because we [an LGBT couple] held hands on the street. ... When I woke up, I wanted to report to the police but when I started to talk and saw the policeman's face, I realized that he was not going to help me. He had such a critical look on his face. I decided not to continue.

To summarize, the set of creative writing assignments enabled the students to become more critical towards societal inequality as well as prompted some of them to become more empathetic towards the groups of people discussed in the assignments.

\section{Research Question 2}

Overall, all the students found the creative writing assignments both engaging and beneficial, which helps to address the second research question about students' attitudes toward the use of creative writing activities. In the end-ofsemester survey, one of the students even noted that he would prefer to write more creative writing exercises rather than academic essays. Another student mentioned that given that student writing is not graded based on grammar, spelling or word choice, he feels "more free" and "it helps you get your thoughts on paper." In addition, some other student noted that as a result of his engagement in the creative writing activities, he had increased both his fluency and confidence as an L2 writer since he "had to focus on the depth rather than the grammar" in his writing. 
While the students appreciated the use of the creative writing exercises, they also found some of the assignments challenging. In particular, two students found the last (fourth) assignment particularly difficult since they described events happening in their home countries. In this assignment, students wrote about the Haitian refugees' situation in the Dominican Republic, the accidental death of an African American in the U.S, the Yazidis' massacre in Iraq, gay rights, and a gypsy's arranged marriage.

In sum, the students admitted that the creative writing assignments helped them with developing greater fluency and confidence in writing, provided that their writing was not graded based on grammar, spelling or structural deficiencies.

\section{Research Question 3}

With regards to the use of critical pedagogy, student perceptions of the use of critical pedagogy in an L2 writing course varied. While most of the students wrote that it was OK to use it in a writing course, one of the students wrote that he really enjoyed "being in another's shoes." Commenting on his overall experience, the same student noted that "I learned how to put myself in that person's shoes, it made me respect and understand others' beliefs." In contrast, one other student mentioned that she would prefer less

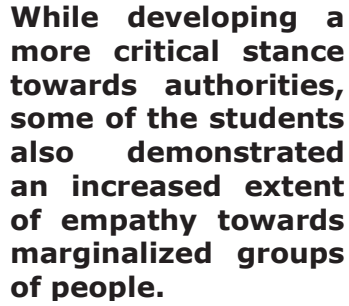

more critical stance towards authorities, some of the students also demonstrated increased extent marginalized groups of people.

depressing topics to write about, thus demonstrating her indifference to the needs of those who find themselves in more dire circumstances than herself.

While developing a more critical stance towards authorities, some of the students also demonstrated an increased extent of empathy towards marginalized groups of people. For example, in her response to the end-of-semester survey, one of the students wrote the following: "This assignment made me more critical towards those people who think that everybody is or should be the same and do not accept people who are different." Another student similarly noted that the assignments "help students think differently." Finally, some other student mentioned that he particularly appreciated learning about social issues and cultural differences through his engagement in the creative writing activities.

\section{Discussion}

To summarize, the majority of the students were positive towards the use of critical pedagogy in an L2 writing course, while one of the students proposed to choose less depressing topics to discuss. Among the benefits of using critical pedagogy, students mentioned learning to think differently, being in another person's shoes, and learning to understand and respect cultural differences.

\section{Limitations of the Study}

Clearly, major generalizations about the use of creative writing exercises and critical pedagogy cannot be made from this research due to the limited sample (nine participants). In the future, a larger and more diverse sample might be a worthwhile research endeavor.

\section{Conclusion}

Overall, the L2 students in this study valued the opportunity to engage in creative writing exercises and benefit from this activity. At the same time, their reactions towards the use of critical pedagogy varied. In this way, the article contributes to the data-driven accounts of international students' experiences with 
creative writing and critical pedagogy. Such research can help renew and revise L2 writing curricula at American universities.

The study suggests that creative writing assignments can serve as an important mediational tool that fosters greater motivation and engagement with writing and argues for the need of more research endeavors in this area. Specifically, it seems worthwhile to trace the impact of creative writing assignments on the quantity and quality of student writing in other course assignments such as academic essays. It can be hypothesized that by extending student opportunities to engage in L2 writing, both the quality and the quantity of their writing will improve.

The analysis also makes clear that creative writing activities grounded in critical pedagogy allow different sources of knowledge for L2 writers to come together. Provided that the majority of students were not familiar with the topics they were required to write about, they engaged in additional research as well as consulted peers and friends who might offer accounts of personal experiences related to the topics discussed in class. The extent to which this actually happens depends a great deal on the abilities of both the instructor and the students to search, synthesize, and interrogate material from a range of sources. Yet, there is potential that ideas from personal experience, classroom, instructor, peers, and expert sources can not only coexist, but also blend and influence one another.

Finally, the study's findings points to the efficacy of creative writing not only as a learning space for L2 students, but also as a way for the instructor to interact with students commenting on the content of student writing, which creates a non-threatening environment for L2 learners to express and develop their ideas in writing.

\section{References}

Bilton, L., \& Sivasubramaniam, S. Lee, H. C. (2012). The reading response (2009). An inquiry into expressive e-journal: An alternative way to engage writing: A classroom-based study. low-achieving EFL students. Language Language Teaching Research, 13(3), Teaching Research, 17(1), 111-131. 301-320.

doi: $10.1177 / 1362168809104702$

Freire, P. (2006). Pedagogy of the oppressed (M. B. Ramos, Trans.). New York, NY: Continuum. (Original work published 1970).

Glaser, B., \& Strauss, A. (1967). The discovery of grounded theory: Strategies for qualitative research. Chicago, IL: Aldine.

Graman, T. (1988). Education for humanization: Applying Paulo Freire's pedagogy to learning a second language. Harvard Educational Review, (58)4, 433-448. Retrieved from http://hepg.org/her-home/home doi: $10.1177 / 1362168812457539$

Leki, L. (1992). Understanding ESL writers: A guide for teachers. Portsmouth, NH: Heinemann.

McDonald, B. A., Rosselli, J. A., \& Clifford, J. E. (1997). Journal writing: Learning, reflections, and adjustments to American life. ERIC Document Reproduction Service No. ED 423709.

Pagliarini Cox, M. I., \& de AssisPeterson, A. A. (1999). Critical pedagogy in ELT: Images of Brazilian teachers of English. TESOL Quarterly, 33(3), 433-452. Retrieved from http://onlinelibrary.wiley.com/journal/1 0.1002/(ISSN)1545-7249

Holmes, V. L., \& Moulton, M. R. (1997). Dialogue journals as an ESL learning strategy. Journal of Adolescent and Adult Literacy, 40(8), 616-621. Retrieved from http://onlinelibrary.wiley.com/journal/1 Pennycook, A. (1990). Critical pedagogy and second language education. System, 18(3), 303-314. Retrieved from http://www.sciencedirect.com/science/j ournal/0346251X 0.1002/(ISSN)1936-2706 
Spack, R., \& Sadow, K. (1983). Studentteacher working journals in ESL freshman composition. TESOL Quarterly, 17(4), 575-593. Retrieved from http://onlinelibrary.wiley.com/journal/1 0.1002/(ISSN)1545-7249

Stillar, S. (2013). Raising critical consciousness via creative writing in the EFL classroom.

TESOL Journal, 4(1), 164-174. doi: 10.1002/tesj.77
Strauss, A., \& Corbin, J. (1998). Basics of qualitative research (2nd edition). Thousand Oaks, CA: Sage.

Zamel, V. (1982). The process of discovering meaning. TESOL Quarterly 16(2), 195-209.

Retrieved from

http://onlinelibrary.wiley.com/

journal/10.1002/(ISSN)1545-7249

Appendix A

Selected Questions from the End-of-Semester Survey

1. Which of the four assignments did you find the most difficult? Why?

2. Overall, did the assignments help you increase your confidence and fluency as a writer? Why (not)?

3. Did your attitude to any of the groups of people change (e.g., you became more empathetic) or remain the same upon completion of the creative writing assignments? Why (not)?

4. Did the creative writing assignments help you become more aware and/or critical towards societal (e.g., gender, racial/ethnic, socioeconomic, etc.) inequality? Why (not)?

5. Would you recommend the use of this set of creative assignments and topics with prospective students? Why (not)? 
Appendix B

Creative Writing Assignments

Assignment 1 "A Day in the Life of a North Korean"

Describe a day in the life of a North Korean from the perspective of the North Korean himself/herself. Carry out basic library research and consult peers or friends, as necessary. Length: 1-2 pages

Assignment 2 "A Letter to an LGBT Friend"

Write a letter from the perspective of a person whose friend is gay, but whose parents do not approve of this friendship. Carry out basic library research and consult peers or friends, as necessary. Length: 1-2 pages

Assignment 3 "A Letter of a Young Saudi Woman"

Write a letter to a U.S. pen friend from the perspective of a young Saudi woman whose intention to study abroad is not supported by her parents. Carry out basic library research and consult peers or friends, as necessary. Length: 1-2 pages

Assignment 4 "A Topic of Your Choice"

Write a letter or a journal entry from the perspective of a person who belongs to a traditionally marginalized societal group. Carry out basic library research and consult peers or friends, as necessary. Length: 1-2 pages

Appendix C

Students' Attitudes and Perceptions of the Creative Writing Assignments

\begin{tabular}{|l|c|c|}
\hline \multicolumn{1}{|c|}{ Selected Survey Questions } & $\begin{array}{c}\text { No (Number of } \\
\text { Students) }\end{array}$ & $\begin{array}{c}\text { Yes (Number of } \\
\text { Students) }\end{array}$ \\
\hline $\begin{array}{l}\text { 1. Did your attitude (e.g., feeling } \\
\text { more empathy) towards any of } \\
\text { the groups of people discussed in } \\
\text { the assignments change? }\end{array}$ & 4 & 5 \\
$\begin{array}{l}\text { 2. Did you become more critical } \\
\text { towards societal inequality? }\end{array}$ & 3 & 6 \\
$\begin{array}{l}\text { 3. Would you recommend the } \\
\text { use of the creative writing } \\
\text { assignments with future } \\
\text { students? }\end{array}$ & 1 & 8 \\
& & \\
\hline
\end{tabular}

InSight: A Journal of Scholarly Teaching 
Ekaterina Arshavskaya is originally from Moscow (Russia). Her MA studies took place in the applied linguistics program at the Montclair State University (NJ) in 2008 and she got her PhD in applied linguistics at Penn State in 2013. She has worked as an EFL/ESL instructor for over 11 years. Her previous work assignment took place at Penn State where she taught academic writing courses to both undergraduate and graduate international students as well as worked with the International Teaching Assistants (the ITAs). Currently, she is an assistant professor of English as a Second Language (ESL) at the Utah State University (Logan, UT). Her research interests include second language (L2) writing and preand in-service L2 teacher education. Dr. Arshavskaya is a member of the American Association of Applied Linguistics (AAAL) and Teaching English to Speakers of Other Languages (TESOL).

Volume $10 \bullet 2015$ 